\title{
Principals' Learning Resources Managerial Practices for Implementing Entrepreneurship Studies in Public and Private Secondary School in Anambra State, Nigeria
}

\author{
Emegwa Tina Uzoamaka \\ Department of Educational Management and Policy, \\ Nnamdi Azikiwe University, Awka, Anambra State, Nigeria
} Abstract:- The purpose of this study was to ascertain
principals' learning resources managerial practices for
the implementation of entrepreneurship studies in
public and private secondary school in Anambra State.
One research question and one hypothesis guided the
study. This study was conducted in public and private
secondary school in Anambra State. The descriptive
survey research design was adopted for this study. The
population for this study is 16,727 respondents made up
of 481 principals and 9,697 teachers from the 481
private secondary schools and 256 principals and 6,293
teachers from the 256 public secondary schools in Anambra state. The sample size for this study is 1,332 respondents drawn from public and private secondary schools in Anambra state. The multi-stage sampling technique was utilized to arrive at the sample size. The first stage involved randomly drawing three education zones out of the six education zones in Anambra state. Accordingly, Aguata, Awka, and Nnewi zones were drawn using simple random sampling technique balloting with replacement. The second stage involved the use of proportionate stratified sampling technique to draw 74 secondary schools from the three education zones, consisting of 26 public and 48 private secondary schools. Each zone was regarded as a stratum. From each stratum, $10 \%$ of principals and teachers were sampled from the public and private secondary schools in the stratum. Researcher-developed instrument was the instrument for data collection. The validity of the instrument was determined using three lecturers. The reliability of the questionnaire was determined using respondents from Enugu State. The Cronbach alpha coefficient of 0.84 was obtained for the instrument. The researcher administered the instruments directly to the respondents with the help of six research assistants who are teachers in the zone. Mean scores were used to answer the research questions while $t$ - test was used to test the hypotheses at 0.05 level of significance. Findings indicated that, in public schools, principals supervise entrepreneurship teachers' use of learning resources in school but in private secondary schools, entrepreneurship teachers are involved in course book selection. Principals in public secondary schools do not motivate subject heads to prepare lesson diaries for teachers in their department but in private schools, students' needs of access to entrepreneurship teaching materials are not met adequately. It was among others recommended that the use of learning resources by entrepreneurship teachers in private schools should be adequately supervised by their principals and students' access to entrepreneurship teaching resource should be enhanced.

Keywords:- Principal; Learning Resource; Managerial Practice; Implementation; Entrepreneurship Studies.

\section{INTRODUCTION}

Entrepreneurship studies encourage and train graduates of secondary schools and higher institutions to take up self-employment since entrepreneurship enhances self employment or self, reliance and promotes national survival. The current massive unemployment of both youths and adults in the country arising from the global economic recession has caused the Nigerian federal government to emphasis the need for all Nigerian citizens to strive for self reliance through self employment. This led to the introduction of entrepreneurship education from primary and secondary school levels (so as to catch them young) and further in tertiary institutions. It is therefore, essential to identify potential ones early at the primary and secondary levels and motivate them into becoming successful entrepreneurs in future. Junaid (2009) affirmed that an entrepreneurship teacher will inculcate the spirit of skill acquisition into a child at early childhood. Besides basic education, an emphasis has been made earlier to the effect that massive entrepreneurial studies and orientation must be injected into the teaming youths as life line and backbone to the present consumption oriented economy. The essence of these drives is that, at the end of the training, the individual would be able to make an enterprise out of any discipline of study. This requires some strategies.

In like manner, Unachukwu (1991) listed some strategies that can be used to motivate children in a learning environment to include giving gift e.g. exercise books, sweet, promising reward, assigning grades, words of encouragement like, 'that is good' 'well done' and punishment. Teachers adopt or apply any or some of these strategies at appropriate teaching and learning situations as they constitute potential learning resources. 
Learning resources refer to those movable assets of the school, which can be moved from one place to another without causing some damages (Hoyle, 2019). They include school facilities that facilitate teaching and learning such as textbooks, chalkboard, teaching aids, computers, laboratory equipment etc. The school principal should endeavour to procure the necessary facilities or resources that will promote quality education in his school and at same time protect, maintain or even replace the obsolete ones. School buildings, equipment, and supplies cost a great deal of money. Therefore, they should be adequately maintained and cared for. The storage and distribution of school supplies and equipment must also receive adequate attention and the custodial staff must be supervised. Some studies have been carried out on entrepreneurship.

Chikeobi, and Ezenduka (2010) studied strategies for enhancing entrepreneurship skills through project instructional method for national economic growth. Results show the accepted strategies for enhancing entrepreneurial skills through project instructional method include helping the prospective entrepreneurs have self-confidence; take calculated risks; be task and result oriented; develop leadership and organizational skills and be energetic and have ability to work long hours. Not only that, Akpotohwo and Amadi (2016) carried a study to determine the perceptions of Business Teacher Educators and small scale business operators on the identified critical factors for successful entrepreneurship. The study adopted a survey research design. Results of this study showed that out of 13 (thirteen) listed critical personal attributes considered relevant for successful entrepreneurship career required of the business education graduates in Delta State, 11 (eleven) were considered very relevant while the remaining 2 (two) were considered not too relevant. Again, from the 9 (nine) critical environmental factors listed as relevant in starting a successful entrepreneurship career by NCE business education graduates in Delta State, 8 (eight) were considered relevant by the respondents and only 1 (one) was considered not too relevant. Finally, the NCE business education graduates and business operators did not differ significantly on the relevance of the listed environmental factors required in starting a successful entrepreneurship career. In a related study, Awoyemi (2019) investigated principals' characteristics and principals' managerial practices for enhancing the teaching of entrepreneurship in secondary schools. The study revealed that effective principals, capable of enhancing the teaching and learning of entrepreneurship were those who were married, aged above 35 years, graduates with teaching qualifications, had one to ten years of teaching experience and were males.

The review so far has shown that managerial practices include a function of several variables. Strong and credible management is at the heart of all achieving organizations, be they private, or public educational institutions. Hence, the principals' managerial practices in public and private secondary schools in Anambra State were determined through variables that ask about how well as principal performed in learning resources managerial practices for the implementation of entrepreneurship studies in the State.
The reason is obvious. The Anambra state government has donated several learning resources for the teaching of entrepreneurship in the state. The problem is that most of those facilities or resources were not effectively utilized in some of the schools. In some schools, especially those located some in rural communities, the facilities are kept in the homes of the community heads for security reasons or due to absence of office accommodations in the schools. In some occasions too, those kept in the schools that require electricity to function were not utilized due to poor electricity supply in the country and Anambra state in particular. The point is that most of those resources were not accessible to the students for whom they were acquired.

\section{$>$ Purpose of the Study}

The main purpose of this study was to ascertain principals' learning resources managerial practices for the implementation of entrepreneurship studies in public and private secondary school in Anambra State.

Research Question: What are the learning resources managerial practices of principals for the implementation of entrepreneurship studies in public and private secondary school in Anambra State?

Null Hypothesis: Principals and teachers in secondary schools do not differ significantly in their mean ratings on how they manage learning resources for the implementation of entrepreneurship studies in Anambra State.

\section{$>$ Research Design}

This study was conducted in public and private secondary school in Anambra State. All the Education zones in the state namely Aguata, Awka, Nnewi, Ogidi, Onitsha, Otuocha were used. The descriptive survey research design was adopted for this study. The population for this study is 16,727 (sixteen thousand, seven hundred and twenty seven) respondents which is made up of 481 principals and 9,697 teachers from the 481 private secondary schools and 256 principals and 6,293 teachers from the 256 public secondary schools in Anambra state. The sample size for this study is 1,332 respondents drawn from public and private secondary schools in Anambra state. The multi-stage sampling technique was utilized to arrive at the sample size. The first stage involved randomly drawing three education zones out of the six education zones in Anambra state. Accordingly, Aguata, Awka, and Nnewi zones were drawn using simple random sampling technique balloting with replacement. The second stage involved the use of proportionate stratified sampling technique to draw 74 secondary schools from the three education zones, consisting of 26 public and 48 private secondary schools. Each zone was regarded as a stratum. From each stratum, $10 \%$ of principals and teachers were sampled from the public and private secondary schools in the stratum. 
Researcher-developed instrument was the instrument for data collection. The validity of the instrument was determined using three lecturers: one in Educational Management and Policy; one in Measurement and Evaluation and one lecturer in Vocational Education, all in Faculty of Education, Nnamdi Azikiwe University, Awka. Their corrections and suggestions were incorporated in the final edition of the instrument. The reliability of the questionnaire was determined by administering copies of the questionnaire to 30 respondents made up of 10 principals and 20 teachers in Enugu State. The scores obtained from the respondents were collated to determine the Correlation co-efficients of the sets of scores for the items in each section were obtained using Cronbach Alpha. The reliability co-efficients of 0.84 was obtained for the instrument. The researcher administered the instruments directly to the respondents with the help of six research assistants who are teachers in the zone. Mean scores were used to answer the research questions while t- test was used to test the hypotheses at 0.05 level of significance.

\section{PRESENTATION OF RESULTS}

Research Question: What are the learning resources managerial practices of principals for the implementation of entrepreneurship studies in public and private secondary school in Anambra State?

\begin{tabular}{|c|c|c|c|c|c|c|c|}
\hline & $\begin{array}{l}\text { Principals' Learning Resources Managerial } \\
\text { Practices in the Implementation of }\end{array}$ & & & $\begin{array}{l}\text { Public } \\
\text { School }\end{array}$ & & \multicolumn{2}{|c|}{$\begin{array}{l}\text { Private School } \\
\qquad(\mathbf{N}=\mathbf{8 6 1})\end{array}$} \\
\hline $\mathrm{S} / \mathrm{N}$ & Items & Mean & SD & Remark & Mean & $\mathrm{SD}$ & Remark \\
\hline 1 & $\begin{array}{l}\text { Adequately meeting the needs of students for } \\
\text { access to entrepreneurship teaching materials in } \\
\text { the school. }\end{array}$ & 2.22 & .90 & Disagree & 2.15 & 1.0 & Disagree \\
\hline 2 & $\begin{array}{c}\text { Ensuring that old entrepreneurship teaching } \\
\text { resources in my school are replaced with new } \\
\text { ones. }\end{array}$ & 2.42 & 1.0 & Disagree & 2.50 & .75 & Agree \\
\hline 3 & $\begin{array}{l}\text { Prioritizing the purchase of entrepreneurship } \\
\text { teaching aids. }\end{array}$ & 2.48 & .82 & Disagree & 2.43 & .91 & Disagree \\
\hline 4 & $\begin{array}{c}\text { Encouraging entrepreneurship teachers to rotate } \\
\text { the utilization of scarce resources among the } \\
\text { classes. }\end{array}$ & 2.49 & .91 & Disagree & 2.50 & .82 & Agree \\
\hline 5 & $\begin{array}{l}\text { Involving entrepreneurship teachers in the course } \\
\text { textbook selection. }\end{array}$ & 2.55 & .71 & Agree & 3.01 & .89 & Agree \\
\hline 6 & $\begin{array}{l}\text { Using personal judgment to approve only } \\
\text { entrepreneurship text books recommended by } \\
\text { examination bodies like NECO and WAEC for } \\
\text { the students. }\end{array}$ & 2.40 & .89 & Disagree & 2.49 & .91 & Disagree \\
\hline 7 & $\begin{array}{l}\text { Encouraging entrepreneurship teachers to ensure } \\
\text { that entrepreneurship teaching materials sent to } \\
\text { classes are used for instructional purposes. }\end{array}$ & 2.43 & .92 & Disagree & 2.30 & 1.0 & Disagree \\
\hline 8 & $\begin{array}{l}\text { Supervising entrepreneurship teachers to ensure } \\
\text { that entrepreneurship teaching materials sent to } \\
\text { workshops are used for instructional purposes. }\end{array}$ & 2.62 & .98 & Agree & 2.47 & .91 & Disagree \\
\hline 9 & $\begin{array}{l}\text { Motivating entrepreneurship subject heads to } \\
\text { prepare lesson diaries for teachers in their } \\
\text { departments. }\end{array}$ & 2.14 & .91 & Disagree & 2.40 & .94 & Disagree \\
\hline & Mean of Means & 2.42 & 0.89 & Disagree & 2.47 & 0.90 & Disagree \\
\hline
\end{tabular}

Table 1:- Mean Ratings on Principals’ Learning Resources Managerial Practices for Implementing Entrepreneurship Studies

The result in table 1 shows that the mean of means for public and private secondary schools are 2.42 and 2.47 respectively. This means that principal and teachers in both public and private secondary schools in Anambra State disagree on the learning resources managerial practices of principals for the implementation of entrepreneurship studies in secondary schools in the area.
The item by item analysis indicates that item 8 with the highest rating of 2.62 for public schools indicates that principals in public secondary schools supervise entrepreneurship teachers to ensure that entrepreneurship teaching materials sent to workshops are used for instructional purposes. Similarly, in private schools, item 5 with the highest mean rating of 3.01 indicates that 
principals in private secondary schools in Anambra State involve entrepreneurship teachers in the course textbook selection.

On the other hand, in public secondary schools, item 9 with the lowest mean rating of 2.14 indicates that principals in public secondary schools do not motivate entrepreneurship subject heads to prepare lesson diaries for teachers in their departments. In the same manner, in private secondary schools, item 1 with the lowest rating of 2.15 indicates that principals in private secondary schools in Anambra State do not adequately meet the needs of students for access to entrepreneurship teaching materials in their schools. The mean of means for public schools $\mathrm{Sd}$ is 0.89 while that of private schools is 0.90 . This is an indication of clustering around the means.

Hypothesis: Principals and teachers in secondary schools do not differ significantly in their mean ratings on learning resources managerial practices for the implementation of entrepreneurship studies in Anambra State.

\begin{tabular}{|c|c|c|c|c|c|c|c|}
\hline $\begin{array}{l}\text { Source of } \\
\text { Variation }\end{array}$ & & & & & & \\
\hline & N & Mean & SD & z-cal & Df & z-crit & Decision \\
\hline Principals & 465 & 2.42 & 0.89 & & & & Significant \\
\hline Teachers & & & & 2.89 & 1325 & 1.96 & \\
\hline
\end{tabular}

Table 2:- t-test of Principals and teachers mean responses on Learning Resources Managerial Practices for the Implementation of Entrepreneurship Studies in Anambra State

The result in table 2 shows that the t-cal value of 2.89 was greater than the critical value t-value of 1.96 at alpha level of 0.05 and degree of freedom (df) 1325. This indicates that there is significant difference in the mean responses of principals and teachers' responses on learning resources managerial practices for the implementation of entrepreneurship studies in Anambra State was significant. Therefore, the null hypothesis was significant.

\section{Summary of Findings}

Base on the data presentation and analysis, the following findings were made:

- Public secondary school principals mobilize PTA and parents to ensure that infrastructural facilities are provided for the teaching of entrepreneurship studies but private secondary schools do not. Private secondary school principals provide generating sets for electricity in their entrepreneurship workshop when there is power failure.

- In public schools, principals supervise entrepreneurship teachers' use of learning resources in school but in private secondary schools, entrepreneurship teachers are involved in course book selection. Principals in public secondary schools do not motivate subject heads to prepare lesson diaries for teachers in their department but in private schools, students' needs of access to entrepreneurship teaching materials are not met adequately.

- Principals and teachers in secondary schools differ significantly in their mean ratings on learning resources managerial practices for the implementation of entrepreneurship studies in Anambra State.

\section{$>$ Discussion of Findings}

Data analysis for research question four revealed that public secondary school principals supervise entrepreneurship teachers in their schools while private school principals involve entrepreneurship teachers in course book selection. It was also found that public secondary school principals do not motivate subject head teachers to prepare lesson diaries for teachers in their department and in private secondary schools, students' needs of access to entrepreneurship teaching materials are not met adequately. Furthermore, data analysis for hypothesis four revealed that there is significant difference in the mean ratings of principals and teachers on learning resource managerial resources for the implementation of entrepreneurship studies in Anambra State.

The findings of this study are analytically important. Supervision is very crucial in teaching and learning activities. For efficiency to be achieved in the school system, teachers' use of instructional materials or learning resources needs to be adequately supervised. Absence of supervision can result in inefficiency and wastages in the system. The private secondary school principals do not supervise their teachers probably because they carry out inspection in most cases to ensure that teachers followed laid down procedures. One interesting finding about private schools is that the principals involve the course teachers in textbook selection. By participating is this exercise, the teachers may feel a sense of belonging to the schools. Most subject teachers know good books and where their opinions were sought, such good books could be recommended for the students. However, a finding about private schools which evokes serious concern is that students' needs of access to entrepreneurship teaching materials are not adequately met in the private secondary schools in Anambra State. It is not enough to have learning resources in schools. The available learning resources should be accessible to the students. This is important in the enhancement of students learning.

The findings of this study were supported by Nwnkwo (2016) who found that public secondary school principals in Ebonyi State supervise their teachers to a great extent. Again, Nwangwu (2007) adequate supervision of both teachers and learning resources to succeed. Again, Adeola 
(2014) found that subject teachers participate adequately in the selection of books for students in private schools. The finding of this study was not supported by Abatam (2015) who fund that there is no significant difference in the mean ratings of principals and teachers on learning resources utilization in private secondary schools. The difference in the findings could be attributed to time or population used. A study carried out in 2015 could not be expected to yield the same result with the one carried out in 2020. Again Abatam studied private secondary schools while the current study was carried out in public secondary schools.

\section{CONCLUSION}

The learning resources must be effectively and efficiently handle for the overall success of entrepreneurship studies. The findings of the study showed that certain learning resources are not efficiently practiced in either or both public and private secondary schools in Anambra State.

\section{RECOMMENDATIONS}

Based on the results of this research, the following recommendations were made:

$>$ Principals in private secondary schools should not only reward their teachers adequately, they should also mobilize PTA to provide learning resources for the teaching of entrepreneurship studies in their schools.

Since text selection is important in teaching and learning activities, public schools should involve their teachers in selecting good entrepreneurship texts for their students.

The use of learning resources by entrepreneurship teachers in private schools should be adequately supervised by their principals and students' access to entrepreneurship teaching resource should be enhanced

\section{REFERENCES}

[1]. Abatam, J.C. (2015). A study of management styles among primary school head teachers in Idemili North Local Government Area of Anambra State, Nigeria. Unpublished master's thesis, Delta State University, Abraka.

[2]. Adebola, D. (2014). School effectiveness and school improvement in Lagos State. School effectiveness and school improvement 7 (2), 133-158. Retrieved on $25^{\text {th }}$ April 2010 from http:// www. iel.org/puts. $\mathrm{Htm} / / 21 \mathrm{st}$.

[3]. Akpotowho, F.C. \& Amahi F.U. (2016).Perception of business teachers educators and critical factors for a successful entrepreneurship. Business Education Journal, 2(2), 72-81.

[4]. Awoymi, S.1. (2019). Assessing entrepreneurial competencies among Nigerian students: The first directed learning approach. Journal of Entrepreneurship Education 3(2) 203 - 227.
[5]. Chikobi, E., \& Ezenduka, O. (2010). Understanding the principles of educational administration. Enugu: New Generation Books.

[6]. Hoyle, D. (2019). Role profiles for managers in different functional areas. Group \& Organization studies, 12(1), 109-118.

[7]. Junaid, M.I. (2009). Teacher preparation and entrepreneurship education. A challenging to the NCCE. A key note address delivered at National Conference on Entrepreneurship Education and the Challenge in the face of Gobal economic crisis. Faculty of Education Nnamdi Azikiwe University, Awka.

[8]. Nwangwu, N.A. (2007). Educational and the law in Nigeria: The rights of teachers and students .Owerri: Kay Bee Cee Publication Ltd.

[9]. Nwankwo, I.N. (2016). Planning for human resources development and utilization in management and supervision of U.B.E. in Ebonyi State. Educational research and study group 2(3) 5-12.

[10]. Unachukwu, G.C. (1991). Appraisal of teachers perceived efficacy of some motivational strategies Abia Journal of Educational Studies 1(1) 82-87. 